\title{
APAKAH PERUBAHAN PLANT LAYOUT DAPAT MENINGKATKAN EFISIENSI PRODUKSI?
}

\author{
Agatha Rinta Suhardi ${ }^{1}$, Ajrina Purnamaputri ${ }^{2}$ \\ ${ }^{1}$ Jurusan S1 Manajemen, Universitas Widyatama Bandung \\ agatha.rinta@widyatama.ac.id \\ 2 Jurusan S1 Manajemen, Universitas Widyatama Bandung \\ ajrinputri17@yahoo.com
}

\begin{abstract}
ABSTRAK
Sektor industri tekstil di Indonesia saat ini menjadi sektor yang berkembang dan memiliki peluang pasar yang besar. Peningkatan proses produksi dipengaruhi oleh layout produksi yaitu tata letak fasilitas yang digunakan. Kapasitas produksi yang maksimal dapat dilakukan dengan meninjau ulang plant layout bagian produksi. Tujuan dari penelitian ini adalah untuk mengetahui gambaran plant layout, kendala yang dihadapi, serta memberikan usulan rancangan layout yang baru pada perusahaan. Metode penelitian menggunakan metode deskriptif. Teknik pengumpulan data menggunakan studi lapangan yang terdiri dari wawancara dan observasi, serta studi kepustakaan. Plant layout perusahaan berupa ukuran ruangan pabrik seluas $30,18 \mathrm{~m}^{2}$, susunan antar mesin terdiri dari 11 unit mesin proses pembuatan dan 237 unit mesin, jumlah produksi benang yang dihasilkan 180 unit per hari, waktu kerja proses produksi benang per hari selama 8 jam yang terbagi dalam tiga shift dalam satu hari, jumlah tugas produksi benang sebanyak tujuh, waktu yang dibutuhkan oleh setiap tugas produksi benang yaitu 720 detik per unit. Kendala yang dihadapi perusahaan adalah jarak antar mesin Bale opener, Super bale opener dan mesin NCF, Simplex berupa Nep (gumpalan kapas), Slub (kerataan sliver atau benang kasar), dan Grains (ukuran berat), Spinning, Ne (nomor benang), TPI (twist per inchi), U\% (kerataan benang), Strenght (kekuatan benang "daya elongation"), dan winding, yang berupa kekuatan dan kerataan sambungan benang, warna cones, lilin pelicin(wax), gulungan crossing (benang silang), dan penulisan lot label. Usulan layout memakai metode line balancing pada perusahaan lebih efisiensi sekitar $75 \%$.
\end{abstract}

Kata kunci : plant layout, efisiensi produksi, metode line balancing

\section{PENDAHULUAN}

Sektor industri tekstil di Indonesia merupakan salah satu sektor industri yang berkembang dan memiliki peluang pasar yang besar. Perkembangan sektor industri tekstil yang begitu pesat telah mengakibatkan semakin banyak pihak yang tertarik untuk terjun ke dalam sektor industri ini. Hal ini terlihat dengan munculnya berbagai perusahaan tekstil baru baik dalam skala besar maupun dalam skala kecil. Setiap industri tekstil yang ada pasti mempunyai ciri khas tentang bagus atau tidaknya barang tekstil tersebut, sehingga dalam pembuatan benang dari bahan-bahan kapas yang berkualitas mempunyai teknik tersendiri dan khas produksi tersebut sehingga para indsutri tekstil kecil mempunyai ciri kualitas yang berbeda-beda dalam hal kualitas bahan baku benang tersebut.

Salah satu perusahaan memproduksi benang menggunakan bahan baku yang berasal dari seratserat alam atau serat-serat buatan baik berupa staple atau filamen. Kapasitas produksi yang maksimal dapat dilakukan dengan meninjau ulang layout produksi. Dengan penggunaan layout yang efektif dan efisien akan membantu peningkatan output ke angka maksimal.

Produksi adalah suatu yang dihasilkan oleh suatu perusahaan baik berbentuk barang maupun jasa dalam suatu periode waktu yang selanjutnya dihitung sebagai nilai tambah bagi perusahaan. (Irham Fahmi, 2010). Plant layout yaitu merupakan suatu keputusan yang menyangkut penyusunan fasilitas operasi secara teratur dan efisien yang mencakup desain atau konfigurasi dari bagian-bagian pusat kerja dan peralatan yang mengacu pada proses produksi (input-prosesoutput), baik yang ada dalam bangunan ataupun di luar sehingga kegiatan operasi berjalan dengan lancar. 
Menurut Gaspersz (2007), line balancing merupakan penyeimbangan penugasan elemen-elemen tugas dari suatu assembly line ke work stations untuk meminimumkan banyaknya work station dan meminimumkan total harga idle time pada semua stasiun untuk tingkat output tertentu.

\section{METODE PENELITIAN}

Dalam penelitian ini yang digunakan penulis adalah metode deskriptif. Metode deskriptif yaitu suatu metode yang bertujuan untuk mendapatkan gambaran mengenai suatu objek atau untuk menggambarkan keadaan perusahaan berdasarkan faktor-faktor yang tampak pada situasi yang dihadapi. Metode ini dilakukan untuk mengetahui dan mampu menjelaskan karakteristik variabel yang diteliti dalam satu variabel. Data yang digunakan untuk penelitian bersumber dari sebuah perusahaan tekstil di Bandung. Data yang diperoleh dari perusahaan kemudian diolah dengan menggunakan Metode Line Balancing.

Pengolahan data dilakukan dengan melakukan analisa terhadap tata letak fasilitas, proses produksi, waktu kerja/jam kerja yang tersedia bagi proses produksi perusahaan, dan jumlah tugas produksi perusahaan.

\section{HASIL DAN PEMBAHASAN}

\section{a. Analisa Proses Plant Layout dan Sistem Produksi perusahaan}

Analisa pertama yang dilakukan adalah melakukan analisa tata letak fasilitas pabrik yang digunakan oleh perusahaan. Peneliti menjelaskan tata letak perusahaan pada, luas ruangan pabrik berada 30,18 $\mathrm{m}^{2}$, Berikut Tabel 1. Jenis Mesin dan Quantity unitnya dapat dijelaskan sebagai berikut:

Tabel 1. Jenis Mesin dan Quantity Unit

\begin{tabular}{|c|l|c|}
\hline No & \multicolumn{1}{|c|}{ Jenis Mesin } & Quantity Unit \\
\hline 1 & Bale Opener & $5 \mathrm{Mesin}$ \\
\hline 2 & Super Bale Opener & $5 \mathrm{Mesin}$ \\
\hline 3 & Beater & $5 \mathrm{Mesin}$ \\
\hline 4 & NCF (Nile Cleaner Feeder) & $5 \mathrm{Mesin}$ \\
\hline 5 & Carding & $62 \mathrm{Mesin}$ \\
\hline 6 & Drawing 1 (breaker 1) & $8 \mathrm{Mesin}$ \\
\hline 7 & Drawing 2 (auto level) & $8 \mathrm{Mesin}$ \\
\hline 8 & Drawing 3 (finisher) & $8 \mathrm{Mesin}$ \\
\hline 9 & Simplex & $13 \mathrm{Mesin}$ \\
\hline 10 & Spinning & $101 \mathrm{Mesin}$ \\
\hline 11 & Winding & $17 \mathrm{Mesin}$ \\
\hline \multicolumn{2}{|c|}{ Total } & $237 \mathrm{Mesin}$ \\
\hline
\end{tabular}

Sumber : Data Perusahaan

Langkah berikutnya dengan melakukan analisa terhadap proses plant layout perusahaan. Proses Plant Layout bagian produksi dapat dijelaskan pada Gambar 1 sebagai berikut : 


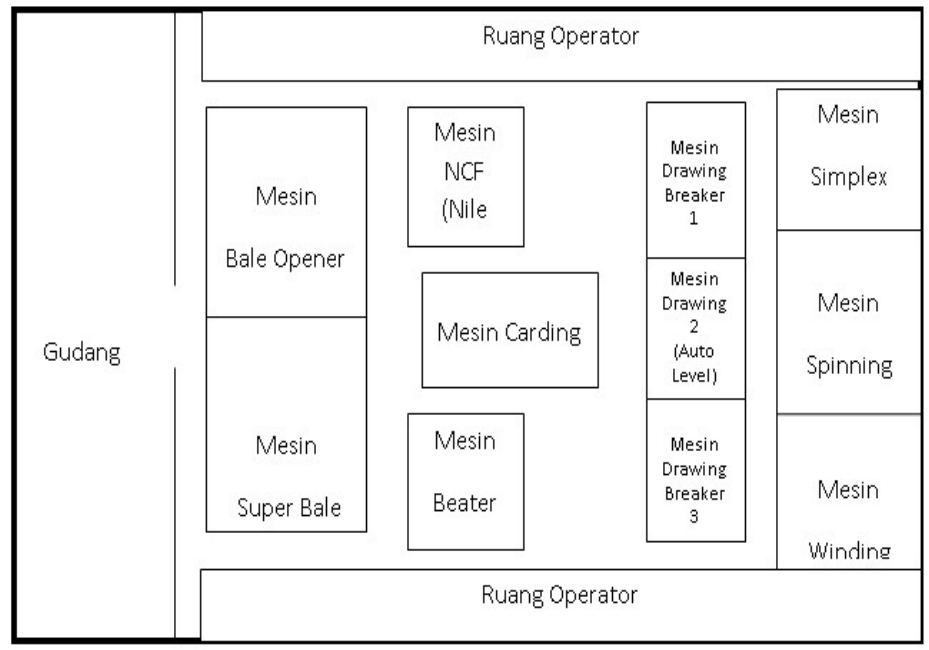

Sumber : Hasil Pengamatan Penulis (2016)

Gambar 1. Denah Proses Produksi Perusahaan

Jumlah tugas produksi benang adalah 7 tugas produksi. Waktu yang dibutuhkan oleh setiap tugas produksi benang untuk menyelesaikan tugasnya adalah 720 detik per unit. Berikut jalur produksi benang:

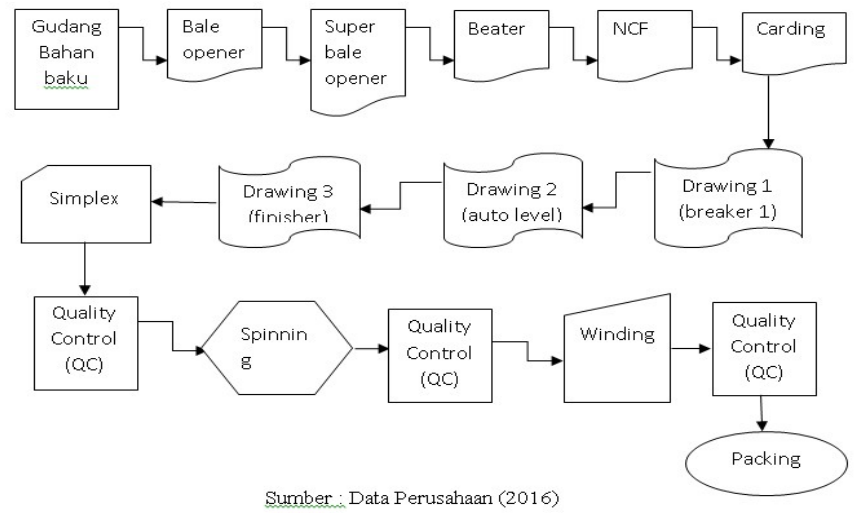

Gambar 2. Jalur Produksi Benang

\section{b. Waktu Pengerjaan Sistem Produksi}

Penghitungan waktu pengerjaan tugas produksi dilakukan dengan menggunakan penghitungan waktu melalui pengamatan langsung terhadap proses kerja dari tiap tugas produksi, di mana waktu pengerjaan diukur menggunakan stopwatch. Untuk mengetahui urutan pengerjaan tugas produksi, maka dilakukan pengamatan urutan pengerjaan terhadap satu unit produk tugas produksi. Urutan pengerjaan tugas produksi terhadap satu unit tugas produksi yang diamati dapat dijelaskan pada Tabel 2 sebagai berikut : 
Tabel 2. Daftar Tugas Produksi

\begin{tabular}{|c|l|c|}
\hline No & \multicolumn{1}{|c|}{ Tugas Produksi } & $\begin{array}{c}\text { Tugas Yang } \\
\text { Mendahului }\end{array}$ \\
\hline 1 & Proses Blowing & 1 \\
\hline 2 & Proses Carding & 2 \\
\hline 3 & Proses Drawing & 3 \\
\hline 4 & Proses Simplex & 4 \\
\hline 5 & Proses Spinning & 6 \\
\hline 6 & Proses Winding & 7 \\
\hline 7 & Proses Packing Sumber: Data Perusahaan (2016) \\
\hline
\end{tabular}

\section{c. Waktu Pengerjaan Tugas Produksi}

Penghitungan waktu pengerjaan tugas produksi dilakukan dengan menggunakan penghitungan waktu melalui pengamatan langsung terhadap proses kerja dari tiap tugas produksi, di mana waktu pengerjaan diukur menggunakan stopwatch. Untuk mengetahui nilai rata-rata waktu pengerjaan tugas produksi, maka dilakukan pengamatan waktu pengerjaan terhadap satu unit produk benang pada masing-masing tugas produksi. Nilai rata-rata dari hasil pengamatan tersebut kemudian dijadikan nilai waktu rata-rata pengerjaan tugas produksi dari masing-masing tugas produksi yang diamati. Waktu pengerjaan tugas produksi dapat dijelaskan pada Tabel 3 sebagai berikut :

Tabel 3. Daftar Tugas Waktu Pengerjaan

\begin{tabular}{|c|l|c|}
\hline No & \multicolumn{1}{|c|}{ Tugas Produksi } & $\begin{array}{c}\text { Waktu Rata-rata } \\
\text { Pengerjaan/Per detik }\end{array}$ \\
\hline 1 & Proses Blowing & 60 \\
\hline 2 & Proses Carding & 80 \\
\hline 3 & Proses Drawing & 180 \\
\hline 4 & Proses Simplex & 80 \\
\hline 5 & Proses Spinning & 80 \\
\hline 6 & Proses Winding & 60 \\
\hline 7 & Proses Packing Jumlah & 180 \\
\hline \multicolumn{2}{|c|}{ Sumber $:$ Data Perusahaan (2016) } \\
\hline
\end{tabular}

Nilai rata-rata waktu pengerjaan tugas produksi, setelah dilakukan pengamatan waktu pengerjaan terhadap satu unit produk benang pada masing-masing tugas produksi dapat diketahui waktu rata-rata pengerjaan adalah 720 detik.

\section{d. Analisa Data Dengan Menggunakan Metode Line Balancing}

Penghitungan Cycle Time Minimum Stasiun Kerja

Dalam melakukan perhitungan waktu siklus (cycle time) dan theoretical minimum (TM) jumlah stasiun kerja, data yang diperlukan adalah data target output produksi adalah 180 unit per hari, data waktu produksi yang tersedia untuk memenuhi target produksi adalah 24 jam $=1440$ menit $=86.400$ detik dan total dari waktu pengerjaan tugas produksi adalah 720 detik per satu unit.

$$
\begin{array}{r}
\text { Cycle Time }-\mathrm{c}-\frac{\text { Wektu tersedia untuk }(\mathrm{r})}{\text { Jurlah Output per heri }(\mathrm{p})}=\mathrm{r} / \mathrm{p} \\
\text { Cylcle time }=\mathrm{c}=\frac{84,400 \text { detik }}{130 \text { unit }}=480 \mathrm{detik}
\end{array}
$$


Sehingga diperoleh Cycle Time adalah 480 detik.

\section{Theoritical Minimum (TM) Jumlah Stasiun Kerja}

Besaran jumlah minimum stasiun kerja yang harus disusun pada lini produksi bagian produksi adalah:

$$
\mathrm{TM}=\frac{\text { Total waktu pengerjean }}{\text { Cycle time }}=\mathrm{t} / \mathrm{c}
$$

$$
\mathrm{TM}=\underline{720 \text { detik }}=1,5=2 \text { stasiun kerja480 detik }
$$

Penyusunan Tugas Produksi ke dalam Stasiun Kerja

Dalam menentukan tugas-tugas produksi mana saja yang dikelompokkan ke dalam setiap stasiun kerja, peneliti menggunakan metode RPW (Ranked Positional Weight). Inti dari metode RPW adalah setiap tugas produksi akan ditempatkan ke dalam setiap stasiun kerja secara berurutan dengan memerhatikan besarnya waktu siklus. Urutan prioritas penempatan tugas ke dalam suatu stasiun kerja akan ditentukan berdasarkan bobot posisi dari tugas produksi tersebut (bobot waktu pengerjaan tugas tersebut ditambah waktu dari tugas yang mengikutinya).

Tabel 4 Pemosisian Tugas Produksi bagian pracetak dengan metode RPW

\begin{tabular}{|c|l|c|c|}
\hline $\begin{array}{l}\text { Tugas } \\
\text { Produksi }\end{array}$ & $\begin{array}{c}\text { Tugas Yang } \\
\text { mengikuti }\end{array}$ & Total Bobot/detik & Stasiun Kerja \\
\hline 1 & $2,3,4,5,6,7$ & 192 & 1 \\
\hline 2 & $3,4,5,7$ & 176 & 1 \\
\hline 3 & $4,5,7$ & 71 & 2 \\
\hline 4 & 5,7 & 21 & 2 \\
\hline 5 & 7 & 16 & 2 \\
\hline 6 & 7 & 13 & 2 \\
\hline 7 & - & 6 & 2 \\
\hline
\end{tabular}

Dari hasil pengelompokan pada Tabel 4 diperoleh pembagian tugas ke dalam stasiun kerja adalah sebagai berikut:

a. Stasiun kerja 1: Tugas 1,dan 2

b. Stasiun kerja 2: Tugas 3, 4, 5, 6, dan 7

\section{Penghitungan Tingkat Efisiensi Lini dan Waktu Kosong}

Langkah selanjutnya, yaitu menghitung tingkat efisiensi lini dan tingkat waktu kosong (idle time). Tingkat efisiensi pada lini produksi benang yaitu :

$$
\text { Idle Time }=\frac{100\left(n-\sum \sum_{i}\right)}{n e} \text { atau Idle Time }=1-\text { Efisiensi }
$$

di mana:

$\mathrm{n}=$ Jumlah stasiun lini

$\mathrm{c}=$ Waktu siklus

$\mathrm{ti}=$ Waktu tugas 


$$
\begin{gathered}
\text { Idle Time }=\frac{100(2 \times 480 \text { detik }-720 \text { detik })}{2(480 \text { detik })} \\
\text { Idle Time }=\frac{100(240 \text { detik })}{(960 \text { detik })} \\
\text { Idle Time }=\frac{24000 \text { detik }}{(960 \text { detik })} \\
\text { Idle Time }=25 \text { detik }
\end{gathered}
$$

Sehingga didapat Idle Time (jeda waktu) dalam dua work station adah 25 detik. Lalu mulai mencari efisiensi produksi. Rumus efisiensi dapat dihitung dengan rumus:

di mana:

$$
\text { Efisiensi }=\frac{t}{N(c)}=\frac{t}{T M(c)}
$$

$\mathrm{t}=$ Total waktu untuk menyelesaikan sebuah unit

$\mathrm{N}=\mathrm{TM}=$ Jumlah work station

$c=$ waktu siklus

$$
\begin{array}{r}
\text { Efisiensi }=\frac{t}{N(c)}=\frac{t}{T M(c)} \\
\text { Efisiensi }=\frac{720 \text { detik }}{2(480 \text { detik })} \\
\text { Efisiensi }=0,75=75 \%
\end{array}
$$

Maka jika dimaasukan ke rumus (3) :

$$
\begin{aligned}
& \text { Idle Time }=1-\text { Efisiensi } \\
& \text { Idle Time }=1-0,75 \\
& \text { Idle Time }=0,25=25 \%
\end{aligned}
$$

Hasil dari persamaan efisiensi akan menunjukkan apakah efisiensi dengan menggunakan theoretical minimum jumlah dua stasiun kerja yang baru memiliki efisiensi yang lebih besar 75 $\%$ dibanding dengan jumlah stasiun kerja yang sebelumnya. Apabila efisiensi menjadi $25 \%$ setelah dimasukan rumus persamaan dan mengalami penurunan, maka kita dapat mengasumsikan jumlah kombinasi stasiun kerja yang telah disusun merupakan pengelompokan stasiun kerja yang optimal.

\section{KESIMPULAN DAN SARAN}

Berdasarkan hasil analisis data menggunakan metode Line Balancing, maka dapat di simpulkan bahwa kendala perusahaan karena material simplex, spinning, dan winding yang sulit dan membutuhkan waktu lebih lama sehingga proses produksi akan membuang banyak waktu sehingga layout menjadi tidak beraturan. Usulan Layout dengan menggunakan metode Line Balancing lebih efisien dengan peningkatan efisien sebesar $50 \%$ (75\% efisiensi dari hasil metode line balancing dan $25 \%$ hasil efisiensi proses produksi). Hal ini menunjukkan bahwa plant layout dengan metode Line Balancing lebih optimal dibanding dengan efisiensi kerja yang telah dijalankan perusahaan. 
Saran yang dapat diberikan berdasarkan kesimpulan yang muncul antara lain saran bagi perusahaan yaitu perlu adanya perencanaan dan penataan ulang layout dari beberapa peralatan tertentu yang menjadi kendala dalam proses produksi yaitu proses simplex, spinning dan winding. Saran lain bagi penelitian mendatang yaitu membahas topik yang sama dengan menggunakan metode penelitian yang berbeda seperti metode bobot, craft sehingga dapat menjadi perbandingan yang konkrit dalam penelitian.

\section{Ucapan Terima Kasih (Acknowledgement)}

Kami ucapkan terima kasih atas bantuan dari berbagai pihak sehingga terlaksananya penelitian ini. Ucapan terima kasih terutama kami sampaikan kepada PT. Apollo Utama Benang yang berkenan sebagai lokasi penelitian ini. Kami sampaikan terima kasih juga kepada Universitas Widyatama yang telah membantu secara administrasi demi kelancaran pelaksanaan penelitian ini dan berbagai pihak yang telah membantu baik secara materiil maupun inmateriil.

\section{REFERENSI}

Abhinav, Shukla, Jyoti, Vimal, dan Vedansh, Chaturvedi. (2013). Analysis of Plant Layout for Reducing Production Cost. IJSRR, Vol 2. No 1, hal.141-147

Arikunto, Suharsimi. (2013). Prosedur Penelitian : Suatu Pendekatan Praktik. Rineka Cipta. Jakarta.

Assauri, Soyjan. (2008). Manajemen Produksi dan Operasi. LPFEUI. Jakarta.

Bordoloi M.P. dan Nath T. (2014). Modification of an Existing Layout of a Production Line Based on Distance Function. The International Journal Of Science Technoledge.

Fahmi, Irham. (2010). Manajemen Kinerja. Alfabet. Bandung.

Heizer, Jay dan Barry Render. (2009). Manajemen Operasi. Edisi 9 Buku 1. Salemba Empat. Jakarta

Heizer, J. \& Render, B. (2011).Operations Management.Tenth Edition. Pearson. New Jersey, USA.

Herjanto, Eddy. (2008). Manajemen Operasi. Edisi Ketiga. Grasindo. Jakarta

Kirtane, Amrita dan Sohani, Nagendra. (2014). Improvement in Plant Layout Using Material Handling Technique. International Journal of Science and Research (IJSR).

Prasetya, Hery dan Lukiastuti, Fitri. (2009). Manajemen Operasi. MedPress. Yogyakarta

Pujotomo, Darminto dan Rusanti, Dian Novia. (2015). Usulan Perbaikan untuk Meningkatkan Produktivitas Filling plant dengan Pendekatan Lean Manufacturing Pada Pt Smart Tbk Surabaya. Jurnal Teknik Industri, Vol X. No.2.

Putri, Karine Santoso, dkk. (2015). Peningkatan Kapasitas Produksi pada PT. Adicitra Bhirawa. Jurnal Titra, Vol. 3, No. 1.

Reksohadiprodjo Sukanto, Indriyo Gitosudarmo. (2008). Manajemen Produksi. BPFE Yogyakarta. Yogyakarta.

Utomo, Budi Setyo dan Sulistiawan, Heri. (2012). Peningkatan Kapasitas Produksi Muffler Menggunakan Metode Line Balancing. Jurnal TI, Vol. 1. No 1, hal 1-16 
MENINGKATKAN EFISIENSI PRODUKSI?

Wignjosoebroto, Sritomo. 2009. Tata Letak Pabrik dan Pemindahan Bahan. Guna Widya. Surabaya. 